\title{
Development Of Montage-Based Learning Module For Drawing Imaginative Picture Lesson For Grade III Students
}

\author{
Ulya Gufroni, Deni Setiawan \\ Primary School Teacher Education Department, Faculty of Education, Semarang State University, Indonesia \\ Corresponding email: ulyagufroni@gmail.com
}

\begin{abstract}
This research is motivated by arts education learning problems in $60 \%$ of students who have not reached the Minimum Exhaustiveness Criteria. Based on the data of the low learning outcomes, efforts are needed to fix the learning process of arts education, especially about teaching materials. This study aims to develop, determine the feasibility of media, and the effectiveness of the use of montage-based learning module on the material to create imaginative images of arts education subjects in third grade Patemon 02 Primary School Semarang District. This research type is Research and Development withmodel development method Borg \& Gall. The results of large-scale test learning have increased with the gain of N-gain of 0.69 which is included in the criterion is. Questionnaire responses students and teachers in good criteria. The conclusion of this research was a montage-based learning module feasible to be used in learning arts education material to create imaginative and effective images for use on learning SBK on student learning outcomes.
\end{abstract}

Keyword: learning module; montage; arts education; imaginative images.

\section{Introduction}

Education is an important thing for somebody to live his life. A nation's quality of life is influenced by the human resources (SDM) of its people. One way to improve the quality of human resources is by improving education. The improvement of the quality of the national education in Indonesia recently is frequently discussed and studied by the educational experts both in central level and local one. Under Undang-Undang Sisdiknas Nomor 20 Tahun 2003 (Act on National Education System: 20/2003), it is explained that education is conscious and systematic measures to create the learning atmosphere and the learning process in order that the students can actively develop their individual potentials to have religiosity, self-control, personality, high intelligence, good characters, and great skill needed by himself, people, nation and the state. The development of the skill can be carried out by formal education by applying school-based curriculum (KTSP). Under Peraturan Menteri Pendidikan Nasional (Permendiknas) nomor 22 Tahun 2006 (Regulation of Minister of Education: 22/2006), the subjects included in School-Based Curriculum (KTSP) are 8 subjects for Primary School degree. The eight subjects are Religiosity, Citizenship, Mathematics, Natural Science, Social Science, Arts Culture and Craftsmanship, Sports, and Indonesian Language.

Arts Culture and Craftsmanship (SBK) is one of the subjects taught in Primary School because the students will get an opportunity to get engaged in various experiences of appreciation and creation of products in form of the concrete objects which have real benefits for the students' lives (Depdiknas, 2007). The teaching of SBK as a subject at school was valuable to the students because this subject contains multilingual, multidimensional, and multicultural values. It has multilingual values means that it aims to develop self-expression skill in various ways. Having multidimensional value means that it develops the students' basic competencies covering perception, knowledge, understanding, analysis, evaluation, apperception, and productivity in terms of balancing the right and left brain, by combining the elements of logics, ethics, and esthetics. While having multicultural value means that it aims to develop the awareness of and the capability of giving appreciation to the diversity of local and global culture to build appreciative, democratic, civilized, and harmonious behavior among the diverse people and culture. (Ahmad Susanto, 2013).

According to International Seminar on Languages and Arts (ISLA) held in 2012, it was stated that the arts and culture teaching nowadays faced many problems both theoretically and practically at school. The subject of arts and culture is regarded as a burden to curriculum. The data of learning outcomes shows that of 30 students consisting of 19 males and 11 females, $60 \%$ (18) did not meet KKM and $40 \%$ (12) exceeded the KKM. The problem regarding SBK learning was found, too, in SDN Patemon 02 District of 
Gunungpati Semarang City. Based on the data of the students' poor learning outcome, we need efforts to ameliorate SBK learning process, particularly concerning the teaching resources for the lesson of drawing imaginative pictures. Due to insufficient teaching tool, I would develop a teaching tool in the form of montagebased module. Montage-based module is an attractive teaching tool for the students. Module is a mold-based teaching resource designed as self-learning tool for the students; thus, module is complimented with the user manual (Asyhar, 2012). Muharrar and Verayanti (2013) stated, montage is a drawing existing or printed on the photographs, newspapers, magazines, and book, it is cut until it is separate from its original sheet. Those pictures are then selected and cut following the wanted object, then they are reduced which means sorting those pictures as needed and adjusted to the theme so that it leaves the clippings to be pasted into a certain composition.

Based on the research that promotes the solution to this problem, i.e. the one conducted by Friska Octavia Rosa Vol. III No. 1 in March/2016 titled "Pengembangan Modul Pembelajaran IPA SMP Pada Materi Tekanan Berbasis Keterampilan Proses Sains" (Development of Science-Process-Skill-Based Module for Natural Science Teaching for Secondary School in Lesson of Pressure). The study shows that the usage of module in the learning had impact on the improvement of motivation and curiosity of the grade VII students of SMP Negeri 3 Batanghari.

Another supporting study is the one conducted by Nofika Setya Andini and Rachma Hasibuan published in 2016 (Vol 05 No 03) titled "Pengaruh Kegiatan Montase Terhadap Kemampuan Motorik Halus Pada Anak Kelompok A" (Impact of Montage Activities on Fine Motor Skill on Group A Children). The study shows that the montage activities has impact on fine motor skill of group A students of TK Aisyiyah Bustanul Athfal 3 Surabaya. Doing activities related to creating montage is expected to have impact on fine motor skills of grade III students.

The research on the development of the learning module was conducted by Michael E. Gorman, Jonathan A. Plucker and Carolyn M. Callahan Vol.79 No. 8/1998 titled "Turning Students into Inventors: Active Learning Modules for Secondary Students". The study shows that the students' problem-solving skill and ability improved after using the learning module.

Based on the benefits obtained from the learning module tested by several accomplished research, thus the application of montage-based learning module to Art, Culture, and Craftsmanship learning is proper. Based on the description above, I am interested in conducting a study titled "Pengembangan Modul Pembelajaran berbasis Montase Mata Pelajaran SBK Materi Membuat Gambar Imjinatif Kelas III SDN Patemon 02 Semarang" (Development of Montage-based Learning Module for Lesson of Drawing Imaginative Picture of Arts, Culture, and Craftsmanship Subject for Grade III Students of SDN Patemon 02 Semarang).

\section{Research Method}

This study used research and development $(R \& D)$ method. The development model that I used was the one reckoned by Borg \& Gall quoted by Sugiyono (2015) that has some respective phases: 1) Problem identification, 2) Information Collecting, 3) Designing Preliminary Form of Product, 4) Preliminary Field Testing, 5) Preliminary Product Revision, 6) Small-Group Field Testing, 7) Operational Product Revision, 8) Large-Group Field Testing, 9) Main Product Revision, 10) Mass Production. This study used saturated sampling as sampling method, which involved all 29 grade III students. This study was conducted in SDN Petemon 02 Semarang City. Subjects in the research were the students, the teacher, the assessors, and the me myself as researcher. The independent variable in the research was the montage-based learning module and the dependent one was SBK learning outcome particularly the lesson of drawing imaginative picture. The data were collected through observation, unstructured interviews, questionnaire, documentation, and testing. The data were analyzed through feasibility test of media and the lesson materials, validity and reliability tests, normality test of pretest dan posttest scores, hypothesis test by average difference assessment, learning outcomes improvement analysis using N-gain equation, as well as analysis of teacher's and students' responses. 


\section{Results And Discussion}

The analysis of the teacher's and students' needs for the design of montage-based learning module, i.e. the applicable new media completed with the pictures easing the students to comprehend the lesson materials. In addition, the lesson materials were presented under the curriculum for primary school and the lesson materials were delivered using the attractive module. The teaching media were displayed in full color and its background was blue. The students wanted the module in $17.5 \times 25 \mathrm{~cm}$ size in a bound ring book, they also like Tahoma font usage at size 14 . The result of the needs analysis became reference to the creation of prototype of montage-based learning module.

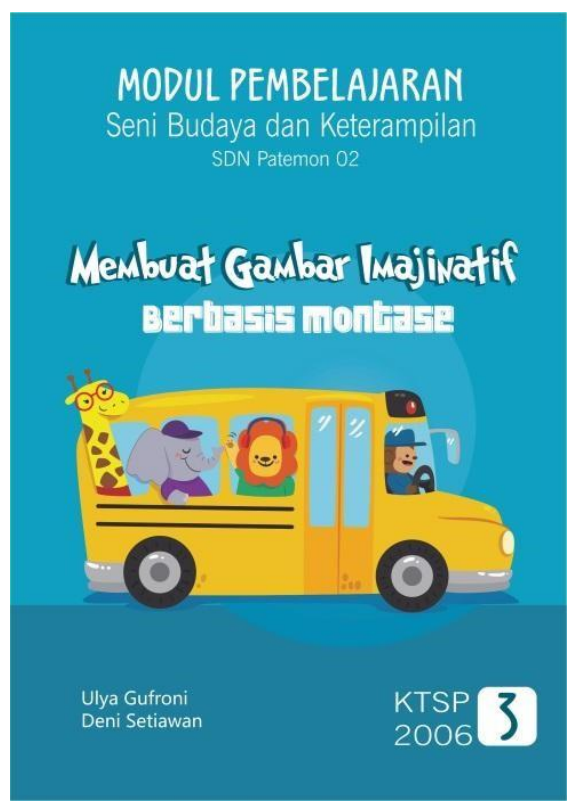

Image 1 Product of Montage Learning Module

The image 1 above is the cover page of montage-based learning module created using Coreldraw $X 7$. The media eased the students to study and enabled them to be active in the learning because they were engaged directly in the drawing of imaginative pictures the examples of which had been included in the module.

The finished media and lesson materials were shown to the assessors. The assessors assessed the feasibility of the media and the lesson materials for each descripture of each indicator by giving score 4 that means excellent, 3 that means good, 2 that means fair, or 1 that means poor. Percentage of feasibility assessment made by the assessors are shown in the following table 1 .
Table 1. Percentage of Feasibility Assessment

\begin{tabular}{lllll}
\hline No Assessor & $\begin{array}{c}\text { Obtained } \\
\text { Score }\end{array}$ & $\begin{array}{c}\text { Max. Feasibility } \\
\text { Score Percentage }\end{array}$ & Remarks \\
\hline 1. $\begin{array}{l}\text { Lesson } \\
\text { Materials }\end{array}$ & 49 & 55 & $89 \%$ & Excellent \\
$\begin{array}{l}\text { Assessor } \\
\text { Media }\end{array}$ & 65 & 75 & $87 \%$ & Excellent \\
2. Assessor & & & & \\
\hline
\end{tabular}

Table 1 shows the given and put-inpercentage score so that the percentage of the media feasibility assessment given by the assessor was $89 \%$ which means excellent and the percentage of lesson materials feasibility assessment given by the assessor was $87 \%$ which means excellent. This is in line with the study conducted by Farid Ahmadi, and Adi Wisnugroho (2016) titled "The Development of Learning Media for Java Scrips Writing Using Macromedia Flash to Improve the Average Learning Outcomes", the study shows that the media assessor gave score percentage $80 \%$ and the lesson material assessor gave score percentage $75 \%$. The media assessor advised to write the lesson material page based on the montage method in order that the students understand the montage method more concretely. The study relevant to this study was the one conducted by Santha Naibaho, Wusono Indarto, Hukmi titled "Pengaruh Kegiatan Montase Terhadap Kemampuan Motorik Halus Anak Usia 5-6 Tahun di TK Tunas Melati Kandis, Kabupaten Siak" (The Impact of Montage Activities on Fine Motor Skill of 5-6 Year-Old Students of TK Tunas Melati Kandis, Siak Regency) which shows that by doing montage activities, the students' fine motor skill bettered. This was shown by the fact that the students could use the writing utensils and they could eat properly, they could draw picture suitable to their ages, they could carry out the exploration by various media and activities, they could express themselves through the movement of drawing in details, they could paste the clippings properly, and they could cut the picture by following the patterns. In addition, the media assessor also advised that the pictures that were made examples must be adjusted to the basic competencies regarding the self. The lesson materials assessor advised to eliminate the multiple-choice questions for the evaluation because they are not suitable for the grade III students whose orientation are learning by playing. This is in line with the study conducted 
by Deni Setiawan (2017) titled "Tipologi Karya Gambar Ekspresi di SDN 02 Wonotirto Kecamatan Bulu Kabupaten Temanggung" (Typology of the Expressive Drawing Works in SDN 02 Wonotirto District of Bulu Temanggung Regency) that shows that the children development stage has impact on the works creation, including the contact with the particular social environment, and gives the extraordinary effect on the artworks creation. I used the advices given by assessors to revise the lesson materials and the questions for the evaluation before it was then experimented.

The finished and feasibility-tested media were then tested in the small group. Based on the small group testing, the application of interactive multimedia comics was effective to boost the students learning outcome, signed by the improvement of learning outcome calculated using N-gain formula about 0.64 which means fair. In the large-group testing, the application of interactive multimedia comics could improve the students learning outcomes, too, at $\mathrm{N}$-gain 0.69 which means fair. It shows that the application of montage-based learning module had impact on the SBK learning outcomes of grade III students of SDN Patemon 02. In the large group testing, the teacher and the students filled in the questionnaire on media application. The followings are the teacher's and students' responses to the montage-based learning module.

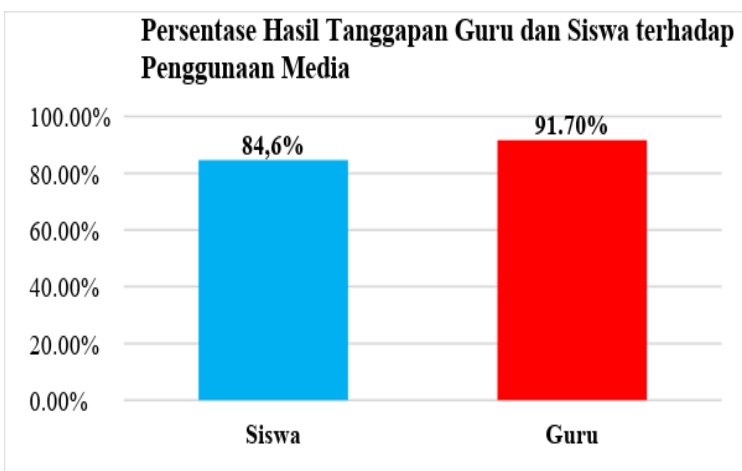

Image 2 Percentage of teacher's and students' responses to the media application

Image 2 shows that the percentage of the teacher's responses was $91.7 \%$ which means excellent. Percentage of the students' responses was $84,6 \%$ which means excellent. It means that the montage-based learning module was excellent to be applied to SBK learning to improve the learning outcomes of the grade III students of SDN Patemon 02. This is relevant with the study conducted by Helda Kusuma Wardani titled "Perbedaan Hasil Pembelajaran IPA antara Pembelajaran Modul Bagian dengan Pembelajaran Konvensional Kelas IV di SDN Jodipan Kota Malang" (The Difference of Natural Science Learning Outcomes between Piece Module Learning and Conventional Learning of Grade IV Students of SDN Jodipan Malang City), the data analysis shows that the piece module learning has significantly different effectiveness from the conventional one.

In the large group testing, from the calculation of pretest scores of grade III students of SDN Patemon 02 to the lesson of drawing imaginative picture of SBK subject using Shapiro-Wilk, it was found that $\mathrm{P}$-value $>\alpha$ i.e. $0.058>0.05$. Meanwhile, P-value of posttest score was $0.119>0.05$. From the calculation above, I can draw a conclusion that the pretest and posttest scores were distributed normally. $\mathrm{N}$-gain test shows that $\mathrm{N}$-gain for the large group was 0.69 . That means that the students have concepts comprehension capacity. Therefore, I can make conclusion that the application of montage-based learning module successfully improved the students learning outcomes and was effective on the large group.

Based on the research, I found that the application of montage-based learning module improved the SBK learning outcomes of grade III students of SDN Patemon 02 Semarang. Montage-based learning module is a selfapplication learning tool combined with montage drawing. The learning implementation applying the montage-based learning module could attract the students' attention and make the students actively engaged in the learning. This learning tool could attract the students' attention, thus, they focused on the learning, they were active, and they could easily catch the lesson, therefore, their learning outcomes improved. This is relevant with what was stated by Santyasa (2009) that module can be used by the students for self-study because it has assessment system based on the learning mastery and it gives the student freedom to learn a lesson based on their own learning speed and capacity. The module can also attract the students' attention and make them more enthusiastically read the learning resource.

The study also strengthens the one conducted by Novita Sariani, Chatarina Muryani, and Mohammad Gamal Rindarjono published in Jurnal GeoEco Vol. 3, No. 1:2017 
titled "Pengembangan Modul Pembelajaran Geografi Berbasis Peduli Ligkungan Untuk Meningkatkan Sikap Peduli Lingkungan Siswa Pada Materi Sumber Daya Alam Di Kelas XI IPS SMA Bina Utama Pontianak" (Development of Environmental AwarenessBased Geography Learning Module for Natural Resources Lesson for Grade XI Students of Social Science Department of SMA Bina Utama Pontianak). Based on the environmental awareness analysis, the percentage of the learning outcome before the application of character-based geography learning module was $63.30 \%$ and after the application of characterbased geography learning module was $85.17 \%$. The application of character-based geography learning module could improve the students' environmental awareness compared to the one before the application

Another study supporting this study was the one conducted by Efi Nilasari, Ery Try Djatmika, Anang Santoso published on Journal of Education , Vol.1, No. 7/2016 titled "Pengaruh Penggunaan Modul Pembelajaran Kontekstual Terhadap Hasil Belajar Siswa Kelas V Sekolah Dasar" (Impact of the Application of Contextual Learning Module on Grade V Students Learning Outcomes). The study shows that the contextual learning module has impact on the learning outcomes of the grade $\mathrm{V}$ students of SD Muhammadiyah 9 Malang.

\section{Conclusion}

Based on the research on development of montage-based learning module, I can draw the following conclusions: (1) This study produced a product in the form of montagebased learning module. The development process of interactive multimedia comics adapted 9 of 10 phases of Borg \& Gall development phases consisting of: 1) Problem identification, 2) Information Collecting, 3) Designing Preliminary Form of Product, 4) Preliminary Field Testing, 5) Preliminary Product Revision, 6) Small-Group Field Testing, 7) Operational Product Revision, 8) Large-Group Field Testing, 9) Main Product Revision, 10) Mass Production; (2) Montagebased learning module is applicable to drawing imaginative picture lesson of SBK learning because it meets the assessment criteria determined by lesson materials and media assessors at percentage of media feasibility given by media assessor $87 \%$ which means "excellent", and the percentage of lesson materials feasibility given by lesson materials assessor was $89 \%$ which means "excellent" with revision. (3) Based on media effectiveness testing, it has significant impact on the students learning outcomes. Grade III students average learning outcomes after applying the montagebased learning module was 86.2 and $\mathrm{N}$-gain was 0.695 which means "fair". The teacher's and students' responses assessment montage-based learning module rated $84.6 \%$ and $91.7 \%$ which means "excellent". From the learning mastery analysis, z-count was 2.94, then it was compared to z-table, i.e. 1.64, thus I can make conclusion that the collective percentage of the students learning outcomes is less than or equal to 75 . the average difference testing analysis shows that the students average posttest score (the test conducted after applying montagebased learning module) was higher than the average pretest one.

\section{References}

Ahmadi, Farid \& Adi Wisnugroho. 2016. The Developing of Media Learning Write Java Letters Using Macromedia Flash to Increase The Average of Learning Result. Annual International Seminar on Transformative Education and Educational Leadership (AISTEEL), 1(1): 508-512

Arsyad, A. 2007. Media Pembelajaran. Jakarta: Raja Grafindo Persada.

Setiawan, Deni. 2017. Tipologi Karya Gambar Ekspresi di SDN 02 Wonotirto Kecamatan Bulu Kabupaten Temanggung. Jurnal Kreatif

Efi Nilasari, Ery Try Djatmika, Anang Santoso. 2016. Pengaruh Penggunaan Modul Pembelajaran Kontekstual Terhadap Hasil Belajar Siswa Kelas V Sekolah Dasar. Jurnal Pendidikan Vol.1, No. 7

Friska Octavia Rosa. 2015. "Pengembangan Modul Pembelajaran Ipa Smp Pada Materi Tekanan Berbasis Keterampilan Proses Sains”. JPF. Vol. III. No. 1.

Wardani, Helda Kusuma. 2013. Perbedaan Hasil Pembelajaran IPA antara Pembelajaran Modul Bagian dengan Pembelajaran 
Konvensional Kelas IV di SDN Jodipan

Kota Malang. Jurnal Pendidikan Sains.

Vol. 1 No. 4

Michael E. Gorman, Jonathan A. Plucker,Carolyn M. Callahan. 1998.

"Turning Students into Inventors: Active

Learning Modules for Secondary Students. $i$ Vol. 79 No. 8

Nofika Setya Andini, Rachma Hasibuan. "Pengaruh Kegiatan Montase Terhadap Kemampuan Motorik Halus Pada Anak Kelompok A". Vol 05 No 03

Novita Sariani, Chatarina Muryani, Mohammad Gamal Rindarjono. 2017. "Pengembangan Modul Pembelajaran Geografi Berbasis Peduli Ligkungan Untuk Meningkatkan Sikap Peduli
Lingkungan Siswa Pada Materi Sumber Daya Alam Di Kelas XI IPS SMA Bina Utama Pontianak”. Jurnal GeoEco Vol. 3, No. 1

Permendiknas Nomor 22 Tahun 2006 tentang Standar Isi Untuk Satuan Pendidikan Dasar dan Menengah.

Santha Naibaho, Wusono Indarto, Hukmi. Pengaruh Kegiatan Montase Terhadap Kemampuan Motorik Halus Anak Usia 56 Tahun di TK Tunas Melati Kandis, Kabupaten Siak. 2017.

Susanto, Ahmad. 2016. Teori Belajar dan Pembelajaran. Jakarta

Sugiyono.2015. Metode Penelitian Pendidikan. Bandung:Alfabeta Sulistyani. 